\title{
Meta-analysis of the association between second-hand smoke exposure and ischaemic heart diseases, COPD and stroke

\author{
Florian Fischer ${ }^{*}$ and Alexander Kraemer
}

\begin{abstract}
Background: Second-hand smoke (SHS) is the most important contaminant of indoor air in first world countries. The risks associated with SHS exposure are highly relevant, because many people are regularly, and usually involuntarily, exposed to SHS. This study aims to quantify the effects of SHS exposure. Therefore, its impact on ischaemic heart diseases (IHD), chronic obstructive pulmonary diseases (COPD) and stroke will be considered.

Methods: A systematic literature review was conducted to identify articles dealing with the association between SHS and the three outcomes IHD, COPD and stroke. Overall, 24 articles were included in a meta-analysis using a random effects model. Effect sizes stratified for sex and for both sexes combined were calculated.

Results: The synthesis of primary studies revealed significant effect sizes for the association between SHS exposure and all three outcomes. The highest RR for both sexes combined was found for COPD (RR = 1.66, 95 \% Cl: 1.38-2.00). The RR for both sexes combined was 1.35 (95 \% Cl: 1.22-1.50) for stroke and 1.27 (95 \% Cl: 1.10-1.48) for IHD. The risks were higher in women than in men for all three outcomes.

Conclusions: This is the first study to calculate effect sizes for the association between SHS exposure and the disease outcomes IHD, COPD, and stroke at once. Overall, the effect sizes are comparable with previous findings in meta-analyses and therefore assumed to be reliable. The results indicate the high relevance of public health campaigns and legislation to protect non-smokers from the adverse health effects attributable to SHS exposure.
\end{abstract}

Keywords: Meta-analysis, Second-hand smoke, SHS, Ischaemic heart disease, COPD, Stroke

\section{Background}

Second-hand smoke (SHS) still remains the most important contaminant of indoor air in first world countries [1]. Despite significant reductions within the past decades, a considerable part of the global population is regularly, and usually involuntarily, exposed to SHS. Therefore, it is a highly important risk factor for the total population. SHS exposure may lead to several chronic conditions, which are highly relevant in terms of morbidity and mortality for a population's health [2]. There is a broad scientific consensus that SHS exposure is linked to carcinogenesis, in particular lung cancer. Furthermore, SHS has been linked to most diseases which are caused by active smoking [3-7]. This association is comprehensible due to the

\footnotetext{
* Correspondence: f.fischer@uni-bielefeld.de

Department of Public Health Medicine, School of Public Health, University of Bielefeld, P.O. Box 10013133501 Bielefeld, Germany
}

more than 50 carcinogens that have been identified in SHS [8].

Several mechanisms may lead to an increased likelihood of adverse effects in the cardiovascular and respiratory system. These mechanisms may cause a reduction in vascular flow and therefore the development of atherosclerosis $[8,9]$. The mechanisms by which SHS exposure increases the risk of heart disease are multiple and interact with each other [10]. In comparison with lung cancer, there is one important difference in the association between SHS exposure and ischaemic heart diseases (IHD): for lung cancer, adverse health effects result from long-term exposure, whereas for other diseases, such as IHD, these effects are not merely long-term and chronic but also acute [11-15]. The effects of even brief passive smoking are often nearly as great as (chronic) active smoking $[10,16,17]$. 


\section{Evidence of adverse health effects attributable to SHS exposure}

Research focused on the associations between SHS exposure and lung cancer first [18]. But subsequently other outcomes, such as IHD [19-21], respiratory diseases [22, 23] and stroke [24-26] were also included in the research. Beginning in 1984, observational studies started to point out the association between SHS exposure and IHD. This seems to be the most important outcome attributable to SHS exposure, because the effects on cardiovascular diseases are obvious even at low doses of SHS exposure $[19,27]$ and because IHDs are much more frequent than lung disease. Because IHD is so prevalent, even a small increase in risk associated with SHS exposure will have a substantial public health impact [28]. Extensive epidemiological research spanning a period of 25 years has indicated that SHS exposure increases the risk of IHD by $25-30 \%[2,10,17,19-21,29]$, and this was also concluded by the Institute of Medicine [30]. The effects still remain if other factors such as dietary intake, socio-economic status, and health-care use are included in the analysis [31].

Furthermore, a dose-response relationship between the level of SHS exposure and the occurrence of IHD was observed [32]. The reported RR of 1.3 (indicating a $30 \%$ excess risk) for the association between SHS exposure and IHD that has been described in several meta-analyses $[12,19,20,33,34]$, is quite large compared to active smoking. The excess risk for regular SHS exposure is about one third of that smoking 20 cigarettes per day, although the total exposure to tobacco smoke is only $1 \%$ of that from 20 cigarettes per day [4, 32]. Assuming a linear dose-response relationship would lead to an expected excess risk associated with SHS exposure of only $0.8 \%$ (1 \% of the $80 \%$ excess risk from smoking 20 cigarettes per day) [35].

Active smoking is the most important risk factor for chronic obstructive pulmonary diseases (COPD). Almost $85-90 \%$ of COPD related mortality is attributable to active cigarette smoking. However, it is also suggested that 10-15\% of COPD cases are attributable to other risk factors such as SHS exposure, occupational exposures, and genetic factors $[22,36]$. Since environmental tobacco smoke contains potent airway irritants, SHS exposure could lead to chronic airway irritation, inflammation, and obstruction $[37,38]$. Nevertheless, up to now the causal association between SHS exposure and COPD has received limited attention in epidemiological studies. The first studies focusing on the association between SHS exposure and COPD faced several limitations. First of all, most studies are based on self-reports and secondly, different methods for defining COPD were used. Therefore, the reported effects of passive smoking on lung function are small and partially inconsistent [22, 39-41].

Comparable to COPD, the relationship between SHS exposure and stroke was not verified for a long time
[8, 42, 43]. In 2014, stroke was included as a condition that is causally linked to SHS exposure in the Surgeon General's Report [44]. After several studies provided overall inconsistent results regarding the association between SHS exposure and stroke [25, 26, 43, 45-48], a metaanalysis of 20 studies indicated a strong dose-dependent association between SHS exposure and stroke [49].

\section{Study objective and research question}

Tobacco use is one of the most important modifiable risk factors for several adverse health effects. Nevertheless, the effects of SHS exposure on health have not yet been fully recognized in public health policies [31, 50]. Although several studies have accounted for the (causal) associations between SHS exposure and disease conditions, some results are still inconsistent. In order to implement demand-actuated and successful strategies to protect the public from adverse health effects attributable to SHS exposure, it is necessary to provide evidence-based information about the magnitude and reliability of associations between SHS exposure and health outcomes. Therefore, this study aims to quantify the effect sizes of SHS exposure for three major outcomes: IHD, COPD, and stroke. Based on the results of a systematic review, a meta-analysis was performed to summarize the results of single studies in one effect size for each of the three outcomes. The main goals of the meta-analysis were: 1) to test whether the study results are homogeneous and, if so, 2) to obtain a combined estimator of the effect magnitude for the association between SHS exposure and the outcomes IHD, COPD and stroke. Although some meta-analyses have dealt with the association between SHS exposure and IHD as well as stroke, this is the first meta-analysis on the association between SHS exposure and COPD. Furthermore, it is the first study that allows a comparison of the effects for the selected outcomes, because the same methodology was used for the systematic literature review and meta-analysis.

\section{Methods}

\section{Systematic literature review}

As a first step, a systematic literature review was performed in PubMed according to the procedure and requirements described in the Preferred Reporting Items for Systematic Reviews and Meta-Analyses (PRISMA) statement [51]. The aim of the systematic review was to identify articles dealing with the association between SHS and the three outcomes (IHD, COPD, and stroke). All relevant literature in English or German language was included without any restrictions regarding the year of publication. The search was restricted to studies on the effects of SHS exposure in humans. The search in PubMed was completed in July 2015. Therefore, the systematic literature review contained articles published between 1984 and 2014. The following search algorithm was performed: 
(second hand smok* [Title/Abstract] OR second-hand smok" [Title/Abstract] OR passive smok" [Title/Abstract] OR "tobacco smoke pollution" [Title/Abstract] OR environmental tobacco smok* [Title/Abstract]) AND (heart disease* [Title/Abstract] OR COPD [Title/Abstract] OR chronic obstructive pulmonary disease* [Title/Abstract] OR obstructive pulmonary disease* [Title/Abstract] OR chronic obstructive airways disease* [Title/Abstract] OR COAD [Title/Abstract] OR chronic obstructive lung disease* [Title/Abstract] OR COLD [Title/Abstract] OR stro$\mathrm{ke}^{*}[$ Title/Abstract] OR apople*[Title/Abstract])

Using the search algorithm under the above-mentioned filters led to the identification of 403 records. Among them, 221 were attributable to a combination of the search terms regarding exposure and the outcome IHD, 178 further articles were attributable to the search terms on COPD and 47 on stroke. ${ }^{1}$ After the screening of title and abstract, 307 of these articles were excluded, because they did not fit the study's objective. Therefore, 96 full-texts were assessed for eligibility. According to this assessment, 71 articles were excluded for the following reasons ${ }^{2}$ :

- study design

- survey/cross-sectional study (9)

- (systematic) review (28)

- meta-analysis (5)

- no effect sizes provided (24)

- other outcomes observed (5)

- other exposures considered (4)

- letter to the editor (2)

- conflict of interest (1)
A manual search was conducted through the reference lists of all full-texts, which led to the inclusion of eight further articles. Finally, 33 articles were included in the qualitative analysis of the systematic review. Before including the studies in the quantitative synthesis in the form of a meta-analysis, a quality assessment was conducted. This quality assessment, which is described in more detail in the following section, led to the exclusion of further 9 studies. The process of the systematic review is presented in a flow chart (Fig. 1).

\section{Quality assessment}

A checklist for the quality assessment was compiled on the basis of already existing and well-established instruments, such as the PRISMA guidelines [51] and instruments developed for observational studies [52-54]. The quality score developed for this study consists of three categories, with four items each. The first category was introduced to identify a selection bias. Therefore, the selection of cases and response rate are focused here. Since both case-control and cohort studies were included in the systematic review, two quality scales were developed which differed slightly in the aspects regarding recruitment of the study population. The second category deals with the assessment of misclassification bias. It is asked 1) whether the exposure evaluation was made in relation to the time of diagnosis, 2) whether the exposure was validated by a biomarker, 3) whether specific disease criteria were provided, and 4) whether the disease was validated by histology or another gold standard. The third category focuses on aspects of data analysis. One item was integrated to detect whether or not an adjustment of variables

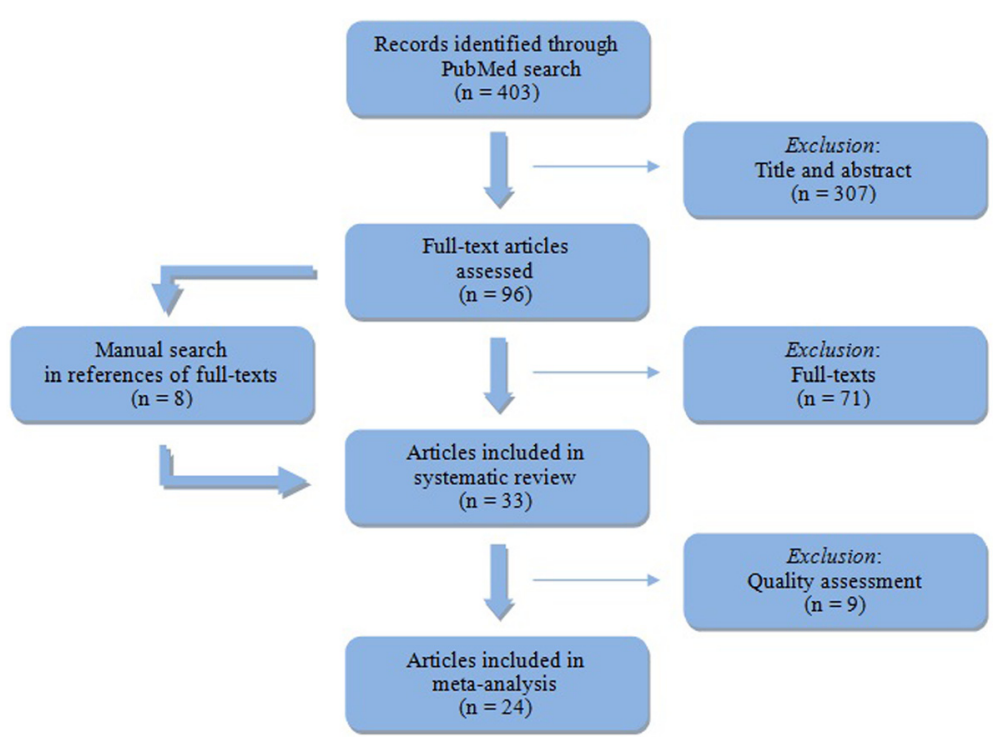

Fig. 1 Flow chart for study selection 
was performed. Additionally, studies with power calculations and sufficient sample size scored higher. A sample size was defined a priori as sufficient if at least 100 subjects were included in the analysis and a minimum of 20 cases occurred, in order to exclude studies with low precision. The last criterion was about the provision of exact $p$-values and confidence intervals $(\mathrm{CI})$.

Each item of the quality score answered with "yes" received one point, and all items with the labels "uncertain/ not reported" or "no" received no points. All points were summed which allows a maximum score of 12 points. A priori, it was decided that all studies with an overall score of 7 points or lower $(n=9)$ would be excluded from the meta-analysis.

\section{Calculation of relative risks}

To allow for comparability between the results of the single studies, those results in which regular SHS exposure was investigated were focused upon. The definition of regular exposure varied between studies. Most commonly, spousal smoking or being exposed to about 20 cigarettes or more per day was interpreted as regular SHS exposure. In case studies divided between SHS exposure at home or at work, only the results for exposure at home were chosen. Nevertheless, several studies only provided information for SHS exposure at home and work combined.

The RR from the cohort studies were directly transferred to the summary of studies presented in Table 1. For case-control studies RR had to be derived from the provided odds ratios (OR). This was done for reasons of comparability of the results and because a single measurement unit was needed for the meta-analysis. For the calculation of RR based on OR an approach introduced by Barendregt [55] was selected. This approach describes the OR as a function of the RR, the average risk of disease in the population (s), and the prevalence of the risk factor (p). The equation uses the assumptions of the common definitions of RR and OR, and the observation that the average risk of a disease in any population is a linear combination of the risk in the exposed and nonexposed sub-populations:

$$
\mathrm{OR}=\frac{\mathrm{RR} \cdot\left(1-\frac{\mathrm{s}}{\mathrm{p} \cdot \mathrm{RR}+1-\mathrm{p}}\right)}{1-\frac{\mathrm{RR} \cdot \mathrm{s}}{\mathrm{p} \cdot \mathrm{RR}+1-\mathrm{p}}}
$$

The reciprocal conversion from $\mathrm{OR}$ to $\mathrm{RR}$ requires a numerical optimization procedure. The detailed derivation of the equation and the Excel add-in for the calculation of $\mathrm{RR}$ is provided by Barendregt [55].

\section{Meta-analysis}

The provided or calculated RRs from the primary studies with high methodological quality were used for the meta-analysis. The meta-analysis was conducted in MIX 2.0 Pro, which is a statistical add-in to perform metaanalysis with Microsoft Excel [56]. As a first step, the RRs and CIs from all the studies were converted into the logarithm function of the RR (log (rr)) and standard errors (se). This information, including the sample size, was used to calculate effect sizes for each of the three outcomes, stratified by sex. The precision was set to an alpha-level of 0.05 and a $\mathrm{z}$-distribution as the standard distribution was chosen. For the analysis, a generic inverse-variance method random effects model was chosen, to provide estimates for the association between SHS exposure and the outcomes IHD, COPD and stroke. In this model, weight is given to each study according to the inverse variance of the effect, to minimize uncertainty about the summarized effect estimates, according to the widely used approach developed by DerSimonian and Laird [57].

\section{Statistical analysis}

The random effects model was chosen, because the data were expected to be heterogeneous across studies. The advantage of a random effects model is that it incorporates variation in the underlying effect sizes between studies. It is assumed that each single study has its own (true) effect and that there is a random distribution of these effects around a central effect [58]. In contrast, using a fixed effect model under conditions of heterogeneity, the $\mathrm{CI}$ for the overall effects reflects the random variation within each study, but not the potential heterogeneity across studies, which would lead to artificially narrow CIs [59]. Furthermore, random effects models are more sensitive to publication bias, due to the larger relative weight given to smaller studies. This implies that a random effects model may still be worth considering as it cannot be assumed that true homogeneity exists across the studies [60].

In order to consider the sensitivity of results, potential publication and study bias were assessed visually using a heterogeneity funnel plot (see Additional file 1). Additionally, heterogeneity was quantified using two statistical measures: The $\mathrm{Q}$ - and $\mathrm{I}^{2}$-statistics reflect a certain dimension of the extent of heterogeneity between the studies. The Q-statistic is the sum of the weighted squared differences between each individual study's estimate and the overall (inverse variance) summary estimates. This statistic follows a $\chi^{2}$-distribution with $k-1$ degrees of freedom, under the null-hypothesis of homogeneity. The Q-test is defined by Hedges and Olkin [61] as:

$$
\mathrm{Q}=\sum \mathrm{w}_{\mathrm{i}} \cdot\left(\mathrm{T}_{\mathrm{i}}-\overline{\mathrm{T}}\right)^{2}
$$

In this equation, $w_{i}$ is the weighting factor for the $i$ th study, $T_{i}$ is the $i$ th effect estimate in a collection of $k$ 
Table 1 Systematic literature review-Overview of all studies

\begin{tabular}{|c|c|c|c|c|c|c|c|c|c|}
\hline Nr. & Authors & Type & Location & Population/Participants & Exposure measurement & Exposure & $\begin{array}{l}\text { Relative Risk } \\
(95 \% \text { Ch) }\end{array}$ & Controlled variables & Score \\
\hline [26] & Bonita et al. (1999) & case-control & New Zealand & $\begin{array}{l}521 \text { patients ( } 279 \text { men, } \\
242 \text { women) 1,851 } \\
\text { controls ( } 934 \text { men, } \\
917 \text { women) }\end{array}$ & self-report & home and workplace & $\begin{array}{l}\text { stroke } \\
1.65(1.28-2.16) \\
\text { men: } 1.87(1.27-2.77) \\
\text { women: } 1.53(1.06-2.2)\end{array}$ & Yes & 9 \\
\hline [72] & Chan-Yeung et al. (2007) & case-control & Hong Kong & $\begin{array}{l}289 \text { patients ( } 243 \text { men, } \\
46 \text { women), } 289 \text { controls } \\
\text { ( } 243 \text { men, } 46 \text { women) }\end{array}$ & self-report & home and workplace & $\begin{array}{l}\text { COPD } \\
1.64(0.97-2.03)\end{array}$ & Yes & 9 \\
\hline [69] & Ciruzzi et al. (1998) & case-control & South America & $\begin{array}{l}336 \text { patients ( } 156 \text { men, } \\
180 \text { women) } 446 \text { controls } \\
\text { (228 men, } 218 \text { women) } \\
\text { never-smokers }\end{array}$ & self-report & home & $\begin{array}{l}\text { IHD } \\
2.04(0.99-12.52)\end{array}$ & Yes & 9 \\
\hline [16] & Ding et al. (2009) & case-control & Hong Kong & $\begin{array}{l}314 \text { female patients, } \\
319 \text { female controls, } \\
\text { never-smokers }\end{array}$ & self-report & home: $\geq 4$ h/day & $\begin{array}{l}\text { IHD } \\
\qquad \text { women: } 1.31(1.03-6.01)\end{array}$ & Yes & 9 \\
\hline [87] & Dobson et al. (1991) & case-control & Australia & $\begin{array}{l}759 \text { patients, ( } 519 \text { men, } \\
240 \text { women) 1,308 } \\
\text { controls ( } 625 \text { men, } \\
683 \text { women) non-smokers }\end{array}$ & $\begin{array}{l}\text { self-report (medical } \\
\text { records and relatives } \\
\text { for deaths) }\end{array}$ & home and workplace & $\begin{array}{l}\text { IHD } \\
\text { men: } 0.98(0.63-1.33) \\
\text { women: } 1.92(1.33-2.69)\end{array}$ & Yes & 9 \\
\hline [88] & Gallo et al. (2010) & cohort & Europe & $\begin{array}{l}\text { 135,233 ( } 19,922 \text { men, } \\
\text { 115,311 women) } \\
\text { never-smokers }\end{array}$ & self-report & home & $\begin{array}{l}\text { stroke } \\
\text { men: } 1.10(0.36-3.37) \\
\text { women: } 0.93(0.49-1.74)\end{array}$ & Yes & 6 \\
\hline [48] & Glymour et al. (2008) & cohort & USA & 16,225 never-smokers & self-report & $\begin{array}{l}\text { home: spousal smoking } \\
\text { (current exposure) }\end{array}$ & $\begin{array}{l}\text { stroke } \\
1.42(1.02-1.92) \\
\text { men: } 1.63(0.83-2.70) \\
\text { women: } 1.46(1.00-2.18)\end{array}$ & Yes & 9 \\
\hline [66] & He et al. (1994) & case-control & China & $\begin{array}{l}59 \text { female patients, } \\
126 \text { female controls, } \\
\text { never-smokers }\end{array}$ & self-report & home & $\begin{array}{l}\text { IHD } \\
\text { women: } 1.16(0.67-1.95)\end{array}$ & Yes & 10 \\
\hline [89] & He et al. (2012) & cohort & China & $\begin{array}{l}910 \text { ( } 439 \text { men, } 471 \text { women) } \\
\text { never-smokers }\end{array}$ & self-report & home and workplace & $\begin{array}{l}\text { IHD } \\
2.15(1.00-4.61) \\
\text { men: } 2.24(0.76-6.59) \\
\text { women: } 2.10(0.69-6.33) \\
\text { COPD } \\
2.30(1.06-5.00) \\
\text { men: } 2.15(0.86-5.39) \\
\text { women: } 3.31 \text { (0.69-15.82) }\end{array}$ & Yes & 7 \\
\hline
\end{tabular}


Table 1 Systematic literature review-Overview of all studies (Continued)

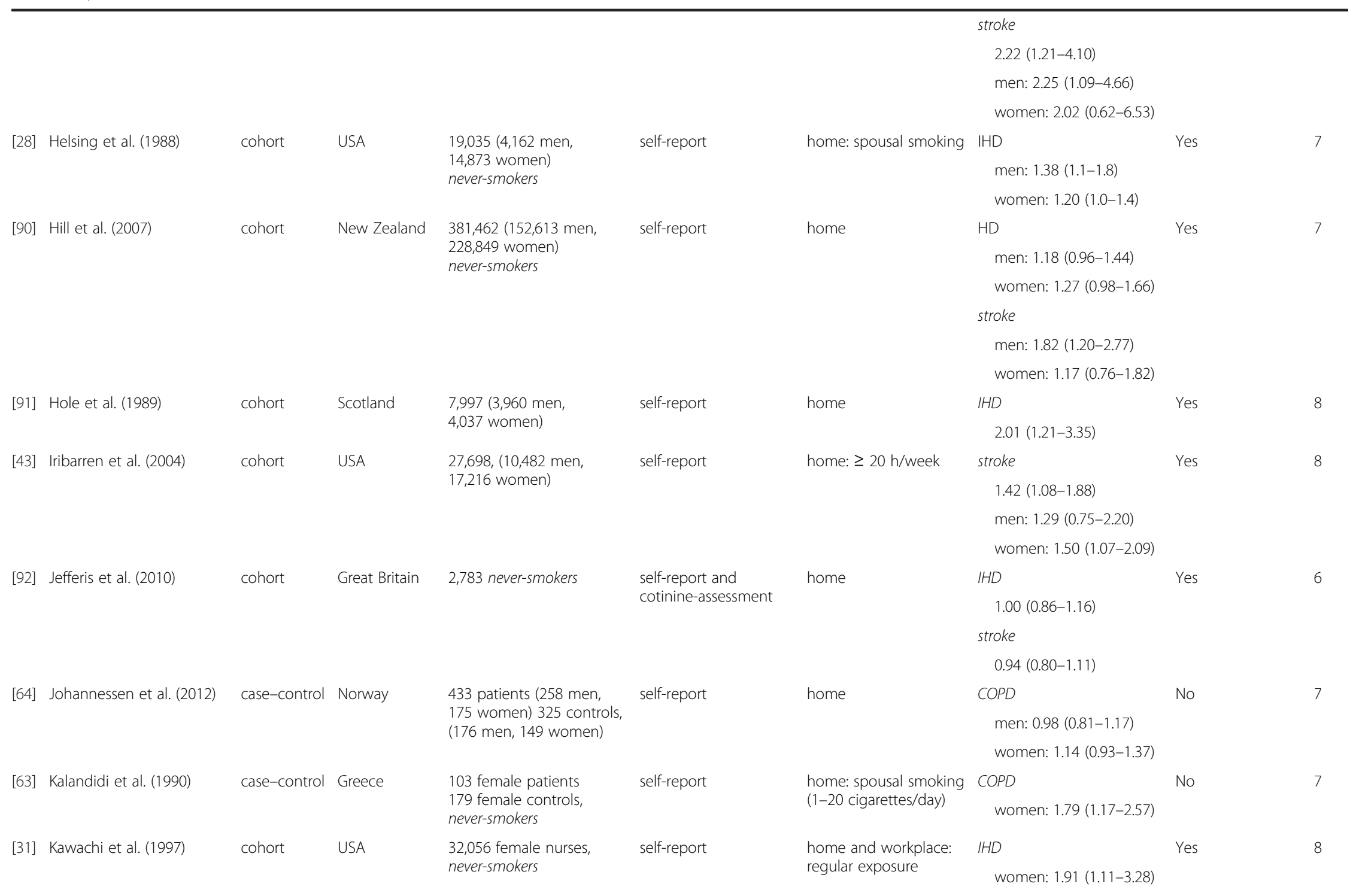


Table 1 Systematic literature review-Overview of all studies (Continued)

\begin{tabular}{|c|c|c|c|c|c|c|c|c|c|}
\hline [70] & McElduff et al. (1998) & case-control & $\begin{array}{l}\text { New Zealand/ } \\
\text { Australia }\end{array}$ & $\begin{array}{l}953 \text { patients ( } 686 \text { men, } \\
267 \text { women), } 3,189 \\
\text { controls, (1,559 men, } \\
\text { 1,630 women) } \geq 10 \text { years } \\
\text { non-smokers }\end{array}$ & self-report & home and workplace & $\begin{array}{l}\text { IHD } \\
\text { men: } 1.01(0.86-1.18) \\
\text { women: } 1.78(1.33-2.36)\end{array}$ & Yes & 9 \\
\hline [24] & McGhee et al. (2005) & case-control & Hong Kong & $\begin{array}{l}4,838 \text { cases ( } 2,680 \text { men, } \\
2,158 \text { women) } 763 \\
\text { controls ( } 418 \text { men, } \\
345 \text { women), } \\
\text { never-smokers }\end{array}$ & self-report & home & $\begin{array}{l}\text { IHD } \\
1.18(1.02-1.36) \\
\text { men: } 1.15(0.93-1.38) \\
\text { women: } 1.22 \text { (0.97-1.53) } \\
\text { COPD } \\
1.81(1.24-2.65) \\
\text { men: } 1.50(0.96-2.28) \\
\text { women: } 2.59(1.30-5.27) \\
\text { stroke } \\
1.24(1.08-1.42) \\
\text { men: } 1.16(0.92-1.44) \\
\text { women: } 1.27(1.06-1.53)\end{array}$ & Yes & 9 \\
\hline [93] & Muscat and Wynder (1995) & case-control & USA & $\begin{array}{l}114 \text { cases ( } 68 \text { men, } \\
46 \text { women) } 158 \text { controls } \\
\text { (108 men, } 50 \text { women) } \\
\text { never-smokers }\end{array}$ & self-report & home and workplace & $\begin{array}{l}\text { IHD } \\
\quad \text { men: } 1.06(0.55-1.83) \\
\text { women: } 1.33(0.71-2.87)\end{array}$ & Yes & 8 \\
\hline [67] & Panagiotakos et al. (2002) & case-control & Greece & $\begin{array}{l}848 \text { cases }(700 \text { men, } \\
148 \text { women) } 1,078 \text { controls } \\
\text { ( } 862 \text { men, } 216 \text { women) } \\
\text { non-smokers }\end{array}$ & self-report & $\begin{array}{l}\text { home and workplace: } \\
\text { regular exposure }\end{array}$ & $\begin{array}{l}\text { IHD } \\
\quad \text { men: } 1.43(1.38-1.47) \\
\quad \text { women: } 1.46(1.41-1.51)\end{array}$ & Yes & 10 \\
\hline [50] & Pitsavos et al. (2002) & case-control & Greece & $\begin{array}{l}848 \text { cases ( } 700 \text { men, } \\
148 \text { women) } 1,078 \text { controls } \\
\text { (862 men, } 216 \text { women) } \\
\text { non-smokers }\end{array}$ & self-report & home: regular exposure & $\begin{array}{l}\text { IHD } \\
\qquad 1.17(1.06-1.61)\end{array}$ & Yes & 9 \\
\hline$[45]$ & Qureshi et al. (2005) & cohort & USA & 3,032 women non-smokers & self-report & home: spousal smoking & $\begin{array}{l}\text { stroke } \\
\qquad 0.8(0.6-1.3)\end{array}$ & Yes & 7 \\
\hline [68] & Rosenlund et al. (2001) & case-control & Sweden & $\begin{array}{l}334 \text { cases (199 men, } \\
135 \text { women) } 677 \text { controls } \\
\text { ( } 401 \text { men, } 276 \text { women) } \\
\text { never-smokers }\end{array}$ & self-report & $\begin{array}{l}\text { home: spousal smoking } \\
\text { (current exposure) }\end{array}$ & $\begin{array}{l}\text { IHD } \\
1.23(0.93-1.57) \\
\text { men: } 0.99(0.67-1.39) \\
\text { women: } 1.79(1.17-2.54)\end{array}$ & Yes & 8 \\
\hline [94] & Rostron (2013) & cohort & USA & 7,586 never-smokers & cotinine-assessed & home: high exposure & $\begin{array}{l}\text { IHD } \\
\qquad 2.47(1.04-5.86)\end{array}$ & Yes & 8 \\
\hline
\end{tabular}


Table 1 Systematic literature review-Overview of all studies (Continued)

\begin{tabular}{|c|c|c|c|c|c|c|c|c|c|}
\hline [95] & Schwartz et al. (2009) & case-control & USA & $\begin{array}{l}562 \text { female cases, } \\
564 \text { female controls }\end{array}$ & self-report & home & $\begin{array}{l}\text { COPD } \\
\text { women: } 1.68(1.12-2.61)\end{array}$ & Yes & 9 \\
\hline [65] & Steenland et al. (1996) & cohort & USA & $\begin{array}{l}309,599 \text { ( } 101,227 \text { men, } \\
208,372 \text { women) } \\
\text { never-smokers }\end{array}$ & self-report & home: spousal smoking & $\begin{array}{l}\text { IHD } \\
\quad \text { men: } 1.22(1.07-1.40) \\
\text { women: } 1.10(0.96-1.27)\end{array}$ & Yes & 7 \\
\hline [73] & Wen et al. (2006) & cohort & China & $\begin{array}{l}72,829 \text { women } \\
\text { never-smokers }\end{array}$ & self-report & $\begin{array}{l}\text { home: spousal smoking } \\
\text { (current exposure) }\end{array}$ & $\begin{array}{l}\text { IHD } \\
\quad \text { women: } 1.37 \text { (1.06-1.78) } \\
\text { stroke } \\
\quad \text { women: } 1.52(1.08-2.15)\end{array}$ & Yes & 8 \\
\hline [96] & Whincup et al. (2004) & cohort & Great Britain & 945 men never-smokers & cotinine-assessment & not specified & $\begin{array}{l}\text { IHD } \\
\quad \text { men: } 1.67(0.91-3.07)\end{array}$ & Yes & 9 \\
\hline$[75]$ & Wu et al. (2010) & case-control & Taiwan & $\begin{array}{l}205 \text { female cases } \\
205 \text { female controls }\end{array}$ & $\begin{array}{l}\text { self-report (validation } \\
\text { by cotinine-assessment } \\
\text { for } 71 \text { subjects) }\end{array}$ & home and workplace & $\begin{array}{l}\text { COPD } \\
\text { women: } 3.12(1.56-6.50)\end{array}$ & Yes & 9 \\
\hline [71] & Yin et al. (2007) & Cohort & China & $\begin{array}{l}15,379 \text { ( } 1,777 \text { men, } \\
13,602 \text { women) } \\
\text { never-smokers }\end{array}$ & self-report & $\begin{array}{l}\text { home: } \geq 5 \text { years of } \\
40 \text { h/week }\end{array}$ & $\begin{array}{l}\text { COPD } \\
1.60(1.23-2.10)\end{array}$ & Yes & 8 \\
\hline [25] & You et al. (1999) & case-control & Australia & $\begin{array}{l}154 \text { cases, } 213 \text { controls, } \\
\text { never-smokers }\end{array}$ & self-report & $\begin{array}{l}\text { home: spousal smoking } \\
\text { ( }>20 \text { cigarettes/day) }\end{array}$ & $\begin{array}{l}\text { stroke } \\
\qquad 1.44(0.96-2.01)\end{array}$ & Yes & 9 \\
\hline [74] & Zhang et al. (2005) & Cohort & China & $\begin{array}{l}60,377 \text { women, } \\
\text { never-smokers }\end{array}$ & self-report & $\begin{array}{l}\text { home: spousal smoking } \\
\text { ( } \geq 20 \text { cigarettes/day) }\end{array}$ & $\begin{array}{l}\text { stroke } \\
\quad \text { women: } 1.62(1.28-2.05)\end{array}$ & Yes & 8 \\
\hline
\end{tabular}


studies and $\bar{T}$ is the estimate of the mean effect size, which consists of weighting every effect estimate $T_{i}$ by its inverse variance. A $p$-value $<0.1$ for the Q-statistic indicates heterogeneity [61].

Afterwards, the $\mathrm{I}^{2}$ is derived from the Q-statistic. The $\mathrm{I}^{2}$-index measures the extent of true heterogeneity by dividing the difference between the results of the $\mathrm{Q}$ test and its degrees of freedom by the Q-value itself, and multiplying by 100 :

$$
\mathrm{I}^{2}=\frac{\mathrm{Q}-(\mathrm{k}-1)}{\mathrm{Q}} \cdot 100
$$

The $\mathrm{I}^{2}$-index quantifies the proportion of inconsistency among the study results. It is commonly expressed as a percentage and is therefore interpreted as the percentage of the total variability in a set of effect sizes due to between-study variation that is not attributable to random sampling from a fixed parameter [62]. Higgins and Thompson [62] proposed a tentative classification of $\mathrm{I}^{2}$ values to help in the interpretation of the heterogeneity's magnitude: according to this classification, percentages of around $25 \%, 50 \%$ and $75 \%$ would mean low, medium, and high heterogeneity, respectively.

\section{Results}

\section{Studies of SHS exposure and selected outcomes}

Overall, 33 studies were included in the systematic review. The first article was published in 1988, and the most recent in 2013. Several of the articles provided information on more than one outcome. Most articles described the effect of SHS exposure on IHD $(n=20)$. In 12 articles stroke was investigated as an outcome and eight articles focused on COPD (Table 1).

The spatial distribution of the study locations of all studies identified by the systematic review is quite equal: nine studies were performed in Asia (mainly in China and Hong Kong), Europe (mainly in Great Britain and northern European countries), and the USA. A further five studies were located in Australia and/or New Zealand and one in South America. Half of the articles described the results of a case-control study $(n=17)$ and the other half used a cohort design $(n=16)$. In almost all studies, information on SHS exposure was based on self-reporting $(n=30)$, while two studies performed a cotinine assessment for measuring SHS exposure and one study used a combination of self-reporting and cotinine assessment (Table 1). Usually, never-smokers or non-smokers were studied. However, some studies did not provide any information on the smoking status of subjects or included active smokers as well as non-smokers. In these cases, smoking status was controlled for in the analyses. All but two studies $[63,64]$ controlled for several factors.
The study samples varied between 309599 neversmokers in a cohort study in the USA, dealing with the association between SHS exposure and IHD [65] and a case-control study with 56 female IHD patients and 136 female controls in China [66].

\section{Effect sizes for SHS exposure and selected outcomes SHS and ischaemic heart disease}

The RR for the single studies dealing with the association between SHS and IHD are presented in Table 2. From the 20 studies on IHD in the systematic review, five were excluded because of low methodological quality according to the quality assessment. Additionally, the Greek study from Panagiotakos et al. [67] was excluded in the meta-analysis, because the same data was used in the study by Pitsavos et al. [50], in which the analysis was stratified by place of exposure. This led to 14 studies on the effects of SHS exposure on IHD. In 6 of these studies, information summarized for both sexes were provided $(n=24903)$. The RR for the association between SHS and IHD was either stratified by sex or only observed for one sex in six studies for men $(n=8208)$ and nine for women $(n=111533)$.

The synthesis of all the studies included in the metaanalysis results in a RR of 1.27 (95\% CI: 1.10 - 1.48) for both sexes together. The RR was much higher for women $(\mathrm{RR}=1.50,95 \% \mathrm{CI}: 1.31-1.72)$ than for men $(R R=1.06,95 \%$ CI: $0.96-1.19)$. None of the studies showed significant results for men regarding the association between SHS exposure and IHD.

The studies from McGhee et al. [24], Pitsavos et al. [50] and Rosenlund et al. [68] had the highest impact on the synthesis, because these three studies were weighted with $88 \%$ overall. The results of Ciruzzi et al. [69], with a very broad confidence interval $(\mathrm{RR}=2.04,95 \% \mathrm{CI}$ : 0.99-12.52), contributed only to a small extent to the overall RR due to the weighting factor of $1.39 \%$. For men, the study by McElduff et al. [70] contributed most to the synthesis result (46.59\%). For women, several studies contributed to more or less the same extent to the synthesis (Table 2, Fig. 2).

Cochran's Q-test revealed no heterogeneity, because the $p$-value was larger than 0.1 for all three subgroup syntheses. This is confirmed by the $\mathrm{I}^{2}$-statistic, which quantifies the assumption between the three different subgroup syntheses. According to the results of these tests, no heterogeneity was observed for men $\left(\mathrm{I}^{2}=0 \%\right)$, and only a small but negligible heterogeneity for the studies focusing on women $\left(\mathrm{I}^{2}=16.00 \%\right)$. $\mathrm{I}^{2}$ was highest for studies including both sexes $\left(\mathrm{I}^{2}=30.78 \%\right)$, because the RR obviously differed for men and women (Table 2).

\section{SHS and chronic obstructive pulmonary disease}

Only five studies investigating the association between SHS exposure and COPD were included in the meta-analysis, 
Table 2 Effect sizes-SHS and ischaemic heart disease

\begin{tabular}{|c|c|c|c|c|c|c|c|}
\hline $\mathrm{Nr}$. & Authors & Sex & $R R(95 \% C l)$ & $\log (r r)$ & se & $n$ & $w(\%)$ \\
\hline [69] & Ciruzzi et al. (1998) & both sexes & $2.04(0.99-12.52)$ & 0.71 & 0.65 & 782 & 1.39 \\
\hline$[16]$ & Ding et al. (2009) & women & $1.31(1.03-6.01)$ & 0.27 & 0.45 & 633 & 2.27 \\
\hline \multirow[t]{2}{*}[87]{} & \multirow[t]{2}{*}{ Dobson et al. (1991) } & men & $0.98(0.63-1.33)$ & -0.02 & 0.19 & 1,144 & 8.35 \\
\hline & & women & $1.92(1.33-2.69)$ & 0.65 & 0.18 & 923 & 12.19 \\
\hline$[66]$ & He et al. (1994) & women & $1.16(0.67-1.95)$ & 0.15 & 0.27 & 185 & 5.87 \\
\hline [91] & Hole et al. (1989) & both sexes & $2.01(1.21-3.35)$ & 0.70 & 0.26 & 7,997 & 7.69 \\
\hline [31] & Kawachi et al. (1997) & women & $1.91(1.11-3.28)$ & 0.65 & 0.28 & 32,056 & 5.72 \\
\hline \multirow[t]{2}{*}[70]{} & \multirow[t]{2}{*}{ McElduff et al. (1998) } & men & $1.01(0.86-1.18)$ & 0.01 & 0.08 & 2,245 & 46.59 \\
\hline & & women & $1.78(1.33-2.36)$ & 0.58 & 0.15 & 1,897 & 16.90 \\
\hline \multirow[t]{3}{*}{ [24] } & \multirow[t]{3}{*}{ McGhee et al. (2005) } & both sexes & $1.18(1.02-1.36)$ & 0.17 & 0.07 & 5,601 & 38.73 \\
\hline & & men & $1.15(0.93-1.38)$ & 0.14 & 0.10 & 3,098 & 29.93 \\
\hline & & women & $1.22(0.97-1.53)$ & 0.20 & 0.12 & 2,503 & 23.48 \\
\hline \multirow[t]{2}{*}{ [93] } & \multirow[t]{2}{*}{ Muscat and Wynder (1995) } & men & $1.06(0.55-1.83)$ & 0.06 & 0.31 & 176 & 3.23 \\
\hline & & women & $1.33(0.71-2.87)$ & 0.29 & 0.36 & 96 & 3.56 \\
\hline$[50]$ & Pitsavos et al. (2002) & both sexes & $1.17(1.06-1.61)$ & 0.16 & 0.11 & 1,926 & 27.88 \\
\hline \multirow[t]{3}{*}[68]{} & \multirow[t]{3}{*}{ Rosenlund et al. (2001) } & both sexes & $1.23(0.93-1.57)$ & 0.21 & 0.13 & 1,011 & 21.40 \\
\hline & & men & $0.99(0.67-1.39)$ & -0.01 & 0.19 & 600 & 8.75 \\
\hline & & women & $1.79(1.17-2.54)$ & 0.59 & 0.20 & 411 & 10.37 \\
\hline$[94]$ & Rostron (2013) & both sexes & $2.47(1.04-5.86)$ & 0.90 & 0.44 & 7,586 & 2.91 \\
\hline [73] & Wen et al. (2006) & women & $1.37(1.06-1.78)$ & 0.31 & 0.13 & 72,829 & 19.64 \\
\hline \multirow[t]{5}{*}{ [96] } & \multirow[t]{2}{*}{ Whincup et al. (2004) } & men & $1.67(0.91-3.07)$ & 0.51 & 0.31 & 945 & 3.15 \\
\hline & & Sex & $R R(95 \% C l)$ & Q & $p$ & $r^{2}$ & \\
\hline & \multirow[t]{3}{*}{ Synthesis } & both sexes & $1.27(1.10-1.48)$ & 7.22 & 0.205 & 30.78 & \\
\hline & & men & $1.06(0.96-1.19)$ & 3.46 & 0.629 & 0.00 & \\
\hline & & women & $1.50(1.31-1.72)$ & 9.52 & 0.300 & 16.00 & \\
\hline
\end{tabular}

after three further studies were excluded because of low quality. Overall, 28965 participants were included in these studies, with more than half of them $(n=15379)$ being investigated in one Chinese cohort study [71]. In three studies the RRs for the association between SHS and COPD were calculated for both sexes combined $(n=21,558)$. Only McGhee et al. [24] provided information stratified for men $(n=3,098)$ and women $(n=2,503)$ and two further studies investigated the association between SHS and COPD in a female-only study population (Table 3).

The large study by Yin et al. [71] accounted for almost half $(49.49 \%)$ of the weighting factor for both sexes. Two further studies, by Chan-Yeung et al. [72] and McGhee et al. [24], accounted for $25 \%$ each for the weighting factor in the subgroup of both sexes. For the female subgroup, the weighting factors were distributed in a similar way for the three studies included, although based on different studies.

The synthesis for both sexes is based on three studies with consistent and significant results. A RR of 1.66 with a comparatively small confidence interval (95\%
CI: $1.38-2.00)$ was calculated. Since the synthesis for men is based on only one study, the RR of 1.50 (95\% CI: 0.96-2.28) was inherited. For women, a higher RR was identified ( $R R=2.17,95 \%$ CI: $1.48-3.18)$ than for men (Table 3, Fig. 3).

The heterogeneity between studies was assessed for the subgroups of both sexes and for women. The Qstatistic and its $p$-value suggested no heterogeneity between study results. The $\mathrm{I}^{2}$ for both sexes was $0 \%$ and for women it was $22.95 \%$, which indicates no or only small heterogeneity (Table 3 ).

\section{SHS and stroke}

The results for stroke are based on seven studies, after five studies were excluded due to the quality assessment. Five studies provided information combined for both sexes $(n=52,263)$. In four studies the analysis was stratified for sex. This leads overall to 22905 male study participants. Two large additional studies focused only on women, which leads overall to 162197 female study participants, which allows for investigating the association between SHS 
Ciruzzi et al. (1998)

Hole et al. (1989)

McGhee et al. (2005)

Pitsavos et al. (2002)

Rosenlund et al. (2001)

Rostron (2013)

Synthesis (both sexes)

Dobsonet al. (1991)

McElduff et al. (1998)

McGhee et al. (2005)

Muscat and Wynder (1995)

Rosenlund et al. (2001)

Whincup et al. (2004)

Synthesis (men)

Ding et al. (2009)

Dobsonet al. (1991)

Heet al. (1994)

Kawachi et al. (1997)

McElduff et al. (1998)

McGhee et al. (2005)

Muscat and Wynder (1995)

Rosenlund et al. (2001)

Wen et al. (2006)

Synthesis (women)

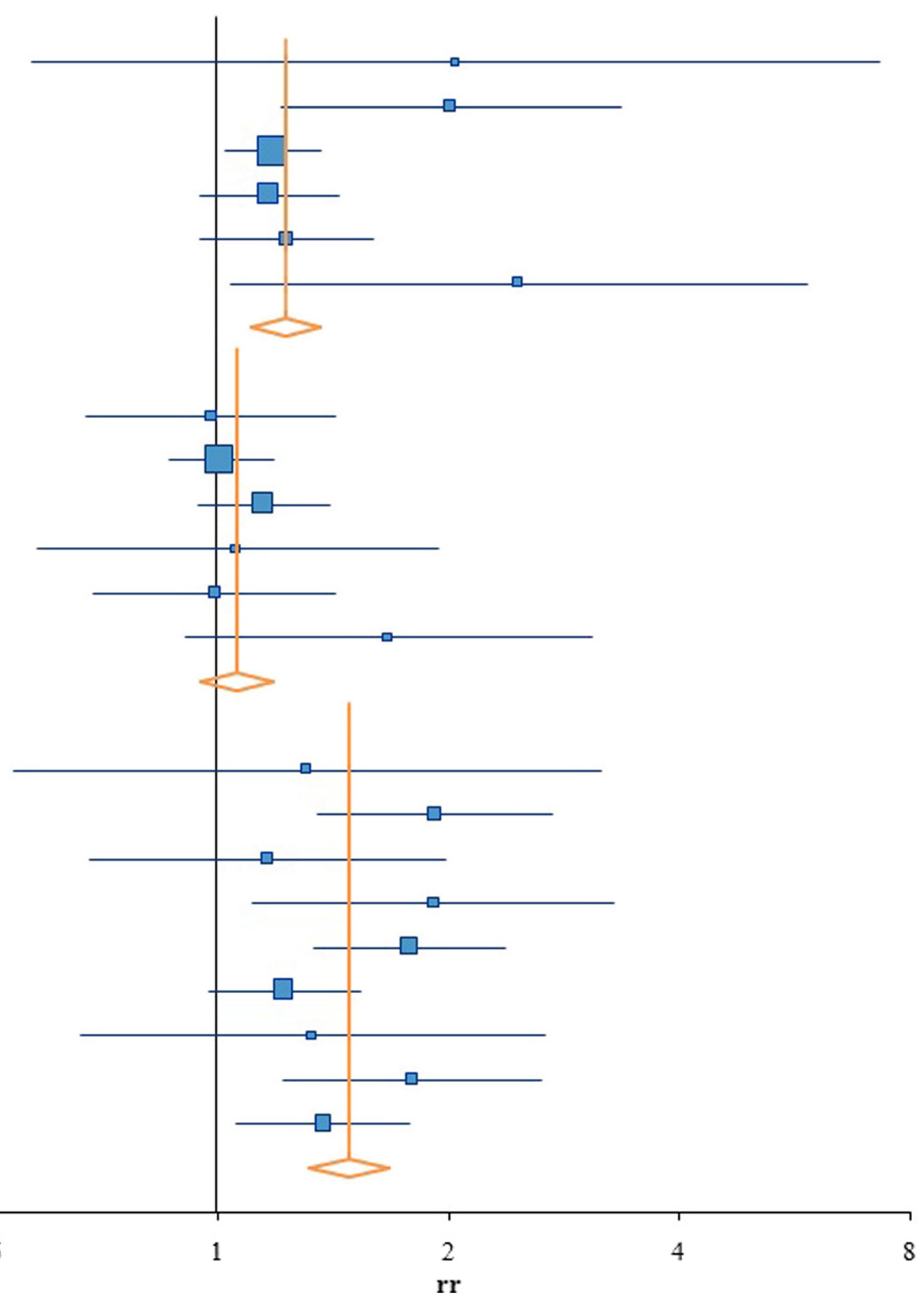

Fig. 2 Forest plot-SHS and ischaemic heart disease

exposure and stroke. For the synthesis of all three subgroups, the study performed by McGhee et al. [24] is of particular importance due to its high weighting factor (Table 4).

The synthesis for the three stroke subgroups differs from the two outcomes for IHD and COPD described above. In this case, the RR for the association between SHS and stroke is 1.35 (95 \% CI: 1.22 - 1.50) for both sexes combined. The analysis separated for sex led to a slightly higher $R R$ for men ( $R R=1.40,95 \%$ CI: 1.09-1.81) as well as for women ( $R R=1.43,95 \% \mathrm{CI}: 1.28-1.61)$ compared to the synthesis for both sexes (Table 4, Fig. 4). This is due to the fact that the studies included in the meta-analysis in which both sexes are considered in a combined effect size are not exclusively the same as those which show results for men or women separately. One study only gives results 
Table 3 Effect sizes-SHS and COPD

\begin{tabular}{|c|c|c|c|c|c|c|c|}
\hline Nr. & Authors & Sex & $R R(95 \% C l)$ & $\log (r r)$ & se & $n$ & $w(\%)$ \\
\hline [72] & Chan-Yeung et al. (2007) & both sexes & $1.64(0.97-2.03)$ & 0.49 & 0.19 & 578 & 25.96 \\
\hline \multirow[t]{3}{*}{ [24] } & \multirow[t]{3}{*}{ McGhee et al. (2005) } & both sexes & $1.81(1.24-2.65)$ & 0.59 & 0.19 & 5,601 & 24.55 \\
\hline & & men & $1.50(0.96-2.28)$ & 0.41 & 0.22 & 3,098 & $100.00^{\mathrm{a}}$ \\
\hline & & women & $2.59(1.30-5.27)$ & 0.95 & 0.36 & 2,503 & 24.69 \\
\hline [95] & Schwartz et al. (2009) & women & $1.68(1.12-2.61)$ & 0.52 & 0.22 & 1,126 & 51.40 \\
\hline [75] & Wu et al. (2010) & women & $3.12(1.56-6.50)$ & 1.14 & 0.36 & 410 & 23.91 \\
\hline \multirow[t]{5}{*}{ [71] } & \multirow[t]{2}{*}{ Yin et al. (2007) } & both sexes & $1.60(1.23-2.10)$ & 0.47 & 0.14 & 15,379 & 49.49 \\
\hline & & Sex & $\operatorname{RR}(95 \% C l)$ & Q & $p$ & $r^{2}$ & \\
\hline & \multirow[t]{3}{*}{ Synthesis } & both sexes & $1.66(1.38-2.00)$ & 0.28 & 0.871 & 0.00 & \\
\hline & & men & $1.50(0.96-2.28)^{a}$ & & & & \\
\hline & & women & $2.17(1.48-3.18)$ & 2.60 & 0.273 & 22.95 & \\
\hline
\end{tabular}

${ }^{a}$ synthesis for men only based on McGhee et al. (2005)

for both sexes combined [25] and two studies only give results for women $[73,74]$.

The Q-statistic indicated no heterogeneity, although the $p$-value for the $\mathrm{Q}$-statistic for men was 0.184 and therefore close to the border indicating heterogeneity. According to the $\mathrm{I}^{2}$, the studies for women $\left(\mathrm{I}^{2}=0 \%\right)$ as well as for both sexes $\left(\mathrm{I}^{2}=2.08 \%\right)$ are homogeneous.
For men, a low to medium heterogeneity was observed $\left(\mathrm{I}^{2}=37.95 \%\right)$ (Table 4).

\section{Discussion}

In this study, the effect sizes for IHD, COPD and stroke attributable to SHS exposure were estimated. For all three outcomes, the effect sizes were larger for women

Chan-Yeung et al. (2007)

McGhee et al. (2005)

Yin et al. (2007)

\section{Synthesis (both sexes)}

McGhee et al. (2005)

Synthesis (men)

McGhee et al. (2005)

Schwartz et al. (2009)

Wu et al. (2010)

Synthesis (women)

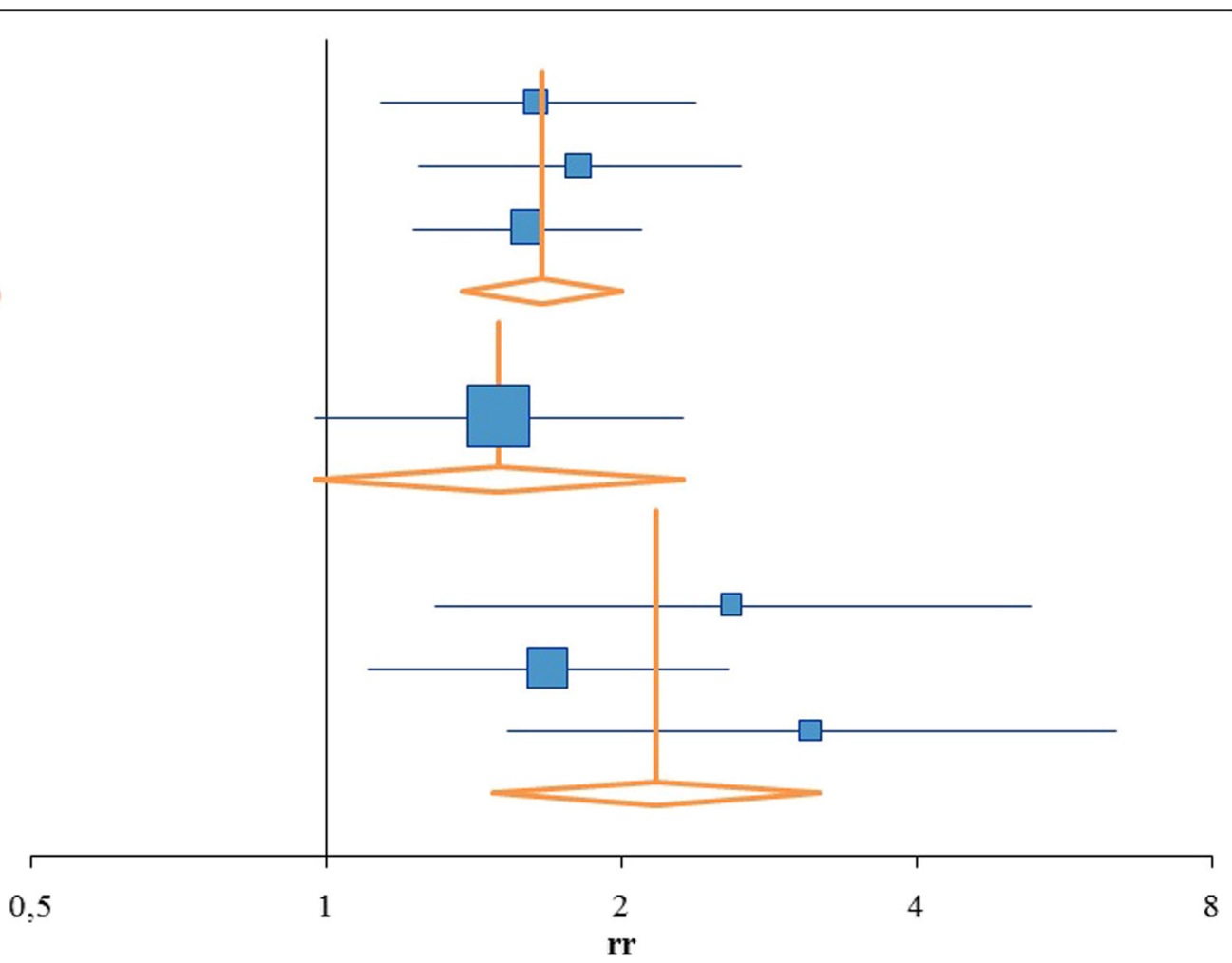

Fig. 3 Forest plot-SHS and COPD 
Table 4 Effect sizes-SHS and stroke

\begin{tabular}{|c|c|c|c|c|c|c|c|}
\hline Nr. & Authors & Sex & $R R(95 \% C l)$ & $\log (r r)$ & se & $n$ & $w(\%)$ \\
\hline \multirow[t]{3}{*}[26]{} & Bonita et al. (1999) & both sexes & $1.65(1.28-2.16)$ & 0.50 & 0.13 & 2,372 & 15.23 \\
\hline & & men & $1.87(1.27-2.77)$ & 0.63 & 0.20 & 1,213 & 25.68 \\
\hline & & women & $1.53(1.06-2.22)$ & 0.43 & 0.19 & 1,159 & 9.27 \\
\hline \multirow[t]{3}{*}{ [48] } & Glymour et al. (2008) & both sexes & $1.42(1.02-1.92)$ & 0.35 & 0.16 & 16,225 & 10.48 \\
\hline & & men & $1.63(0.83-2.70)$ & 0.49 & 0.30 & 8,112 & 14.39 \\
\hline & & women & $1.46(1.00-2.18)$ & 0.38 & 0.20 & 8,113 & 8.34 \\
\hline \multirow[t]{3}{*}[43]{} & Iribarren et al. (2004) & both sexes & $1.42(1.08-1.88)$ & 0.35 & 0.14 & 27,698 & 13.60 \\
\hline & & men & $1.29(0.75-2.20)$ & 0.25 & 0.27 & 10,482 & 16.56 \\
\hline & & women & $1.50(1.07-2.09)$ & 0.41 & 0.17 & 17,216 & 11.30 \\
\hline \multirow[t]{3}{*}{ [24] } & McGhee et al. (2005) & both sexes & $1.24(1.08-1.42)$ & 0.22 & 0.07 & 5,601 & 52.98 \\
\hline & & men & $1.16(0.92-1.44)$ & 0.15 & 0.11 & 3,098 & 43.38 \\
\hline & & women & $1.27(1.06-1.53)$ & 0.24 & 0.09 & 2,503 & 37.59 \\
\hline [73] & Wen et al. (2006) & women & $1.52(1.08-2.15)$ & 0.42 & 0.18 & 72,829 & 10.68 \\
\hline$[25]$ & You et al. (1999) & both sexes & $1.44(0.96-2.01)$ & 0.36 & 0.19 & 367 & 7.71 \\
\hline \multirow[t]{5}{*}{ [74] } & Zhang et al. (2005) & women & $1.62(1.28-2.05)$ & 0.48 & 0.12 & 60,377 & 22.83 \\
\hline & & Sex & $R R(95 \% C l)$ & $Q$ & $p$ & $P^{2}$ & \\
\hline & Synthesis & both sexes & $1.35(1.22-1.50)$ & 4.08 & 0.395 & 2.08 & \\
\hline & & men & $1.40(1.09-1.81)$ & 4.84 & 0.184 & 37.95 & \\
\hline & & women & $1.43(1.28-.61)$ & 3.02 & 0.697 & 0.00 & \\
\hline
\end{tabular}

than for men. In men, statistically significant results were revealed only for the association between SHS exposure and stroke. According to the calculated effect sizes for all three disease entities, the risk factor of SHS exposure seems to be particularly important for COPD. A $66 \%$ excess risk of COPD was calculated for people exposed to SHS for both sexes combined. For stroke $(\mathrm{RR}=1.35,95 \% \mathrm{CI}: 1.22-1.50)$ and $\mathrm{IHD}(\mathrm{RR}=1.27$, 95 \% CI: 1.10-1.48), the RR was considerably lower.

\section{IHD}

The calculated association between SHS exposure and IHD is consistent with several meta-analyses calculating the overall RR of coronary heart diseases associated with SHS exposure among non-smokers. In a meta-analysis including 18 studies (10 prospective cohort studies and eight case-control studies), the estimated RR was 1.25 (95 \% CI: 1.17-1.32) [20]. A meta-analysis by Wells [12] focused on the association between IHD mortality and SHS exposure. According to this study, a RR of 1.23 (95\% CI: 1.12-1.35) was calculated for both sexes combined (men: $\mathrm{RR}=1.25,95 \% \mathrm{CI}$ : 1.03-1.51; women: $\mathrm{RR}=1.23$, $95 \% \mathrm{CI}: 1.11-1.36$ ) [12]. These estimations are comparable to the calculation of the effect size for both sexes combined. Nevertheless, the study by Wells [12] provided effect sizes which are almost equal for both sexes. In our study the results for the association between SHS exposure and IHD indicated much higher effect sizes for women. Wells [12] also calculated the effect size associating IHD morbidity with SHS exposure. Here, the RR for women was 1.51 (95\% CI: 1.16-1.97), which is comparable to the estimation of the results of our study. Therefore, it seems that the associations for IHD morbidity and mortality differ substantially, and this leads to differences in the effect sizes estimated in this study compared to previous ones.

\section{COPD}

The estimation of the effect size for the association between SHS exposure and COPD cannot be compared to other meta-analyses, because this is the first attempt to calculate a synthesis for the primary studies dealing with this association. Up to now, the number of studies on SHS exposure as a risk factor for adult onset COPD is small compared with the number on the adverse health effects of SHS exposure on childhood respiratory symptoms and diseases [22]. The estimation for both sexes combined led to a RR of 1.66 (95 \% CI: 1.38-2.00), which is higher than the estimation for the association between SHS exposure and IHD. This also applies to the gender stratified estimations: in women a RR of 2.17 was calculated with a fairly broad confidence interval (95 \% CI: 1.48-3.18). This can be explained by the fact that three of the total of five studies dealt with the association in women. The studies by Wu et al. [75] $(\mathrm{RR}=3.12$, 95 \% CI: 1.56-6.50) and McGhee et al. [24] 
Bonita et al. (1999)

Glymour et al. (2008)

Iribarren et al. (2004)

McGhee et al. (2005)

You et al. (1999)

Synthesis (both sexes)

Bonita et al. (1999)

Glymour et al. (2008)

Iribarren et al. (2004)

McGhee et al. (2005)

Synthesis (men)

Bonita et al. (1999)

Glymour et al. (2008)

Iribarren et al. (2004)

McGhee et al. (2005)

Wen et al. (2006)

Zhang et al. (2005)

Synthesis (wom en)

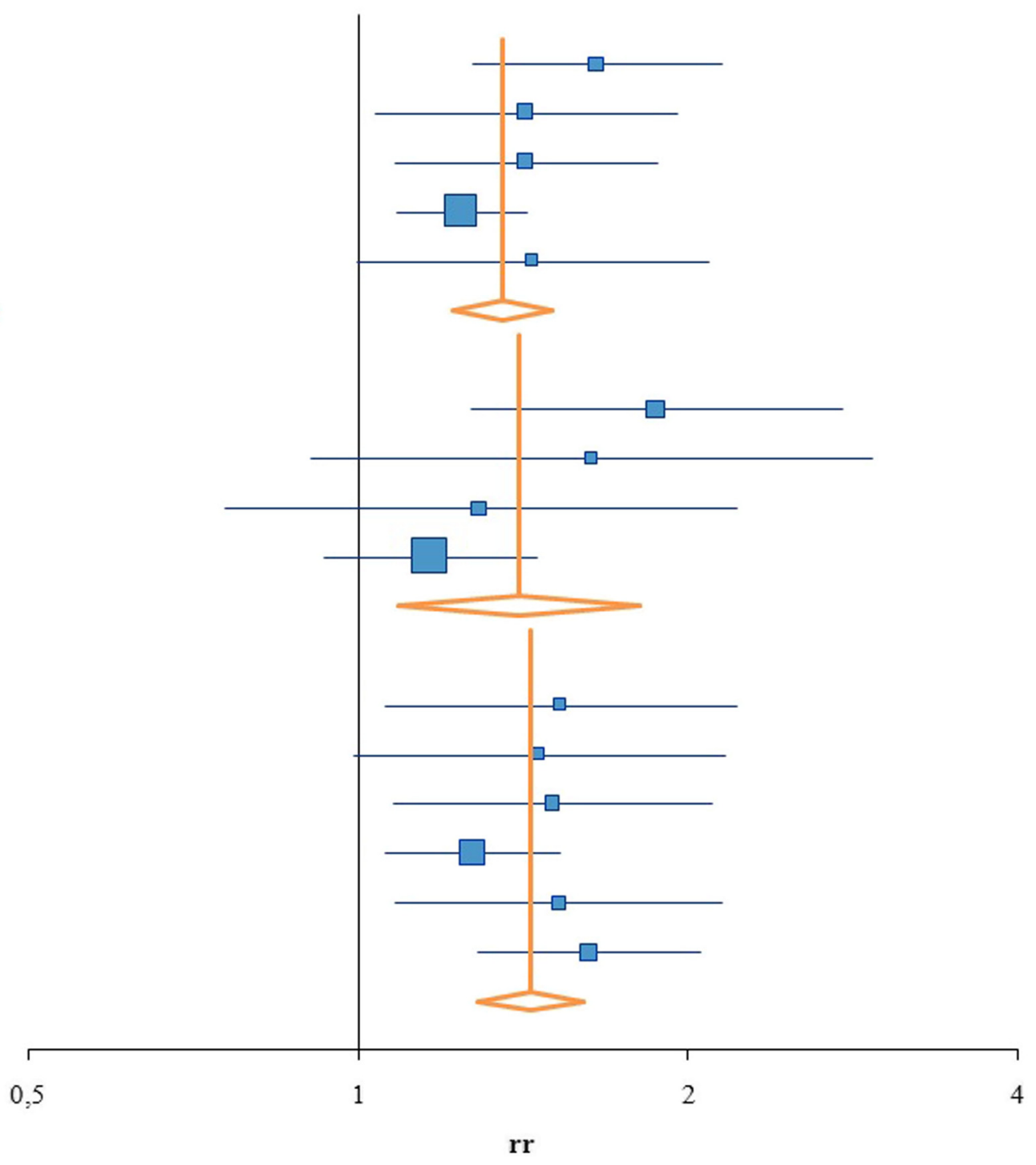

Fig. 4 Forest plot-SHS and stroke

$(\mathrm{RR}=2.59,95 \% \mathrm{CI}: 1.30-5.27)$ in particular contributed to the broad confidence interval. Therefore, the few existing studies on SHS exposure and COPD differ considerably, although the results indicate a positive association. No judgement on the consistency of the results of primary studies on the association between SHS exposure and COPD for men is possible, because only the study by McGhee et al. [24] provided results for the male subgroup (RR $=1.50$, 95 \% CI: 0.96-2.28).

\section{Stroke}

The estimations for the association between SHS exposure and stroke ( $\mathrm{RR}=1.35,95 \% \mathrm{CI}$ : 1.22-1.50) are comparable with previous meta-analyses. In our study, the effect sizes showed a significantly increased risk for people exposed to
SHS in both sexes, with RRs that are almost equal between men $(\mathrm{RR}=1.40$, $95 \% \mathrm{CI}: 1.09-1.81)$ and women (RR1.43, 95 \% CI: 1.28-1.61). Lee and Forey [76] provided a comprehensive review of epidemiological evidence relating stroke to SHS exposure in lifelong non-smokers. Overall, including 16 studies (seven prospective cohort studies, six case-control studies and three cross-sectional studies) which used current spousal smoking (or nearest equivalent) as the exposure index led to an overall estimate of 1.25 (95\% CI: 1.16-1.36), which is slightly lower than our calculations. The study results also indicated no significant heterogeneity and no differences between men and women [76], which is consistent with our study results. Eight studies in the meta-analysis provided information regarding a possible dose-response relationship between 
SHS exposure and stroke. According to this, the synthesis for the highest level of exposure led to a RR of 1.56 (95\% CI: 1.34-1.82).

Another meta-analysis [49], included 20 studies (10 cohort studies, six case-control studies and four crosssectional studies) published between 1984 and 2010. All of these reported results for non-smokers, who were mainly defined as never-smokers, although some studies also included ex-smokers or infrequent current smokers. Eleven studies in the meta-analysis by Oono et al. [49] measured the dose of SHS exposure, which was either defined as the number of smokers, cigarettes per day, hours per week, pack years, or cotinine concentration and score. Our calculations for the effect size of the increased risk of stroke attributable to SHS exposure $(\mathrm{RR}=1.35,95 \% \mathrm{CI}: 1.22-1.50)$ are in line with the results of SHS exposure of either 10 cigarettes per day $(\mathrm{RR}=1.31,95 \% \mathrm{CI}: 1.12-1.54)$ or 15 cigarettes per day $(\mathrm{RR}=1.45,95$ \% CI: $1.19-1.78)$ [49].

\section{Dose-response relationship}

The results of the primary studies that were included in the meta-analysis on the associations between SHS exposure and IHD as well as stroke indicate a distinct dose-response relationship. Even low levels of SHS exposure increase the risk of adverse health effects, indicating that there is no safe level of exposure [42, 49]. The effects of SHS exposure are lower than those of active smoking, but it has been consistently shown that the effects of SHS exposure on the cardiovascular system are much larger than might be expected from a comparison of the doses of toxins delivered to active and passive smokers. Therefore the effects of SHS are estimated to be on average 80-90\% as harmful as those of active smoking [10]. The effects of a dose-response relationship between SHS exposure and adverse health outcomes were not depicted in this study, because it focused on regular exposure to SHS. Although the dose-response function might supply important additional information, Sauerbrei et al. [77] argued that aggregated data are too limited to perform a meta-analysis including a dose-response analysis. Nevertheless, regular SHS exposure, irrespective of the dose is still an important risk factor, because it may lead to both acute and chronic diseases.

\section{Gender differences}

The stratification for sex performed in this study is highly relevant, because the effect sizes as well as the prevalence of diseases and the prevalence of SHS exposure differ between the sexes. Until now, it has been largely men who have been considered in many studies dealing with IHD, because of their higher prevalence of coronary diseases. In most parts of the world women are at least $50 \%$ more likely to be exposed to SHS than men [78]. Until now, only a few studies have investigated possible mechanisms underlying sex differences in adverse health outcomes such as IHD related to SHS exposure. It is assumed that the anti-oestrogenic effect of cigarette smoking-and therefore also the exposure to SHS-may be at least partly related to the increased risk of IHD in young females smokers [79]. Furthermore, a study by Geisler et al. [80] indicated that in smoking women undergoing oestrogen replacement therapy, plasma levels of oestrogen were 40-70 \% lower than in non-smoking women. Additionally, a decrease in both oestradiol and testosterone concentrations in smoking men has been reported [81]. Therefore, hormonal factors seem to considerably influence vulnerability due to SHS exposure. This might be one explanation for gender differences in the effects of SHS exposure [82].

\section{Limitations}

There are methodological restrictions in data quality of primary studies, which have to be considered when interpreting the results. Among these, particularly the differences in study designs and misclassification bias due to different definitions and measurements of SHS exposure have to be mentioned. Another limitation of major importance in the context of a systematic literature review is a possible publication bias, although a review of published and unpublished studies on the health effects of SHS exposure showed no evidence of publication bias against statistically non-significant results in the peer-reviewed literature [83].

Another limitation in the identification of primary studies on the association between SHS exposure and the three selected diseases leads back to the decision to perform the systematic literature search only in one literature database, PubMed. Therefore, some studies might have been missed, although an additional manual search in the reference lists of publications was performed, which led to only eight further articles. A broader search strategy with another search algorithm may have led to further articles eligible for the meta-analysis.

The quality assessment led to the exclusion of nine studies. Although the development of criteria for the quality assessment was based on established instruments, different criteria may have led to the exclusion of more or fewer articles, depending on their strictness. The quality checklist was used as a scale, although the criticism has been made that these scales do not provide a transparent estimation of the degree of bias [84]. Furthermore, quality scores neglect information about individual items and no empirical basis for the different weights that are implicitly given to each item exists [85]. Nevertheless, this approach was chosen, to allow for the exclusion of studies with low methodological quality.

Since only cohort studies and case-control studies were selected, a large number of studies had to be excluded either during the screening of titles and abstracts or during 
the assessment of full-texts. Also, comparatively small studies with low effect sizes or rather broad confidence intervals were included in the meta-analysis. These studies carried a smaller weight in the synthesis of results. To make the results of the primary studies comparable, all the OR provided in case-control studies were re-calculated into RR using quite a conservative approach, which is more likely to underestimate the true association. Therefore, overall, the effect sizes calculated in the meta-analysis represent a conservative estimate.

Besides the identification and data quality of primary studies, the combination of research results from multiple studies performed in the meta-analysis faces several limitations and uncertainties. Although this meta-analysis indicates only low heterogeneity, diversity between studies, for example due to different populations (e.g., countries, age groups), inclusion and exclusion criteria (e.g., more severe patients), study designs (e.g., inadequate follow-up of lost patients), statistical methods used, and various sources of bias, is still an important issue. Formal heterogeneity tests face low statistical power. In this study, the Qstatistic and $\mathrm{I}^{2}$-test were used. A shortcoming of the Q-statistic is that it has low power to detect true heterogeneity among studies when the meta-analysis includes only a small number of studies [86]. The Q-statistic is useful to test for the existence of heterogeneity, but not to assess the magnitude of heterogeneity. For that we used the $\mathrm{I}^{2}$.

For the calculation of the effect sizes for COPD, it has to be kept in mind that the estimation for men is based on only one study. Particularly for COPD, the synthesis is based on very few studies, which limits its reliability. The combination of studies will often result in small confidence intervals, suggesting a false precision [58]. In this context, it is relevant to point out that random effects models, as used in this study, are not sufficient to explain the heterogeneity between studies, since the random effect merely quantifies an unexplained variation by estimating it [59].

\section{Conclusion and implications}

Up to now, the effects of SHS exposure on population health are still controversial, although several studies and meta-analyses have revealed comparable results on the association between regular SHS exposure and adverse health outcomes. However, further studies with sound methodological approaches due to large prospective epidemiological studies using biomarkers for exposure assessment are still required to determine the risks associated with SHS exposure $[16,76]$. Furthermore, there is only a little evidence for the effects of SHS on health-related quality of life, which is a very important parameter for well-being besides objective parameters such as morbidity and mortality.

To address this research need, this study was conducted. It is the first study to have calculated effect sizes for the association between SHS exposure and the disease outcomes IHD, COPD, and stroke, stratified by sex. The effect sizes calculated in the meta-analysis are overall comparable with previous findings in meta-analyses for IHD and stroke. This suggests that the results are reliable. Although no previous meta-analysis for the association between SHS exposure and COPD is available, the results are assumed to be reliable as well, because the methodological approach in this study was the same for all three disease entities. Nevertheless, further research is needed, to provide more adequate primary studies which account for confounding and other biases.

\section{Endnotes}

${ }^{1}$ Because some articles dealt with multiple outcomes, the sum of all articles did not add up to 403 .

${ }^{2}$ The number of articles excluded for each criterion is mentioned in brackets. The sum did not add up to 71 , because some articles were excluded for multiple reasons.

\section{Additional file}

Additional file 1: Caption: Heterogeneity funnel plots. (DOCX $20 \mathrm{~kb}$ )

\section{Competing interests}

The authors declare that they have no competing interests.

\section{Authors' contributions}

FF and AK conceptualized the study. FF analysed and interpreted the data, AK supervised the process. FF drafted the manuscript and AK revised the manuscript critically for important intellectual content. All authors read and approved the final manuscript.

\section{Acknowledgements}

We wish to thank Elizabeth Sourbut for English language editing. This analysis received no funding. We acknowledge support of the publication fee by the Deutsche Forschungsgemeinschaft and the Open Access Publication Funds of Bielefeld University.

Received: 30 July 2015 Accepted: 12 November 2015 Published online: 01 December 2015

\section{References}

1. Öberg M, Jaakkola MS, Woodward A, Peruga A, Prüss-Üstun A. Worldwide burden of disease from exposure to second-hand smoke: a retrospective analysis of data from 192 countries. Lancet. 2011;377(9760):139-46.

2. Heidrich J, Wellmann J, Heuschmann PU, Kraywinkel K, Keil U. Mortality and morbidity from coronary heart disease attributable to passive smoking. Eur Heart J. 2007;28(20):2498-502.

3. Vineis $P$, Airoldi L, Veglia F, Olgiati L, Pastorelli $R$, Autrup $H$, et al. Environmental tobacco smoke and risk of respiratory cancer and chronic obstructive pulmonary disease in former smokers and never smokers in the EPIC prospective study. BMJ. 2005:330(7486):277.

4. Hackshaw AK, Law MR, Wald NJ. The accumulated evidence on lung cancer and environmental tobacco smoke. BMJ. 1997;315(7114):980-8.

5. Wells AJ. Lung cancer from passive smoking at work. Am J Public Health 1998;88(7):1025-9.

6. Wald NJ, Nanchahal K, Thompson SG, Cuckle HS. Does breathing other people's tobacco smoke cause lung cancer? Br Med J. 1986;293(6556):1217-22.

7. Lee PN, Chamberlain J, Alderson MR. Relationship of passive smoking to risk of lung cancer and other smoking-associated diseases. $\mathrm{Br} J$ Cancer. 1986;54(1):97-105 
8. U.S. Department of Health and Human Services. The Health Consequences of Involuntary Exposure to Tobacco Smoke. In: A Report of the Surgeon General. Atlanta, GA: U.S. Department of Health Human Services; 2006.

9. Powell JT. Vascular damage from smoking: disease mechanisms at the arterial wall. Vasc Med. 1998;3(1):21-8.

10. Barnoya J, Glantz SA. Cardiovascular effects of secondhand smoke: nearly as large as smoking. Circulation. 2005;111(20):2684-98.

11. Davis JW, Shelton L, Watanabe IS, Arnold J. Passive smoking affects endothelium and platelets. Arch Intern Med. 1989;149(2):386-9.

12. Wells AJ. Passive smoking as a cause of heart disease. J Am Coll Cardiol. 1994;24(2):546-54

13. Callinan JE, Clarke A, Doherty K, Kelleher C. Legislative smoking bans for reducing secondhand smoke exposure, smoking prevalence and tobacco consumption. Cochrane. 2010;4:Cd005992.

14. Dinas PC, Metsios GS, Jamurtas AZ, Tzatzarakis MN, Wallace Hayes A, Koutedakis $Y$, et al. Acute effects of second-hand smoke on complete blood count. Int J Env Health Res. 2014;24(1):56-62.

15. Dacunto PJ, Cheng K-C, Acevedo-Bolton V, Jiang R-T, Klepeis NE, Repace $J$, et al. Identifying and quantifying secondhand smoke in source and receptor rooms: logistic regression and chemical mass balance approaches. Indoor Air. 2014:24(1):59-70

16. Ding D, Wing-Hong Fung J, Zhang Q, Wai-Kwok Yip G, Chan CK, Yu CM. Effect of household passive smoking exposure on the risk of ischaemic heart disease in never-smoke female patients in Hong Kong. Tob Control. 2009;18(5):354-7.

17. Lippert WC, Gustat J. Clean Indoor Air Acts reduce the burden of adverse cardiovascular outcomes. Public health. 2012;126(4):279-85.

18. Ahijevych K, Wewers ME. Passive smoking and vascular disease. J Cardiovasc Nurs. 2003;18(1):69-74.

19. Law MR, Morris JK, Wald NJ. Environmental tobacco smoke exposure and ischaemic heart disease: an evaluation of the evidence. BMJ. 1997:315(7114):973-80.

20. He J, Vupputuri S, Allen K, Prerost MR, Hughes J, Whelton PK. Passive smoking and the risk of coronary heart disease-a meta-analysis of epidemiologic studies. N Engl J Med. 1999;340(12):920-6.

21. Thun M, Henley J, Apicella L. Epidemiologic studies of fatal and nonfata cardiovascular disease and ETS exposure from spousal smoking. Environ Health Perspect. 1999;107 Suppl 6:841-6.

22. Coultas DB. Passive smoking and risk of adult asthma and COPD: an update. Thorax. 1998:53(5):381-7.

23. Jindal SK, Gupta D. The relationship between tobacco smoke \& bronchial asthma. Indian J Med Res. 2004;120(5):443-53.

24. McGhee SM, Ho SY, Schooling M, Ho LM, Thomas GN, Hedley AJ, et al Mortality associated with passive smoking in Hong Kong. BMJ. 2005;330(7486):287-8.

25. You RX, Thrift AG, McNeil JJ, Davis SM, Donnan GA. Ischemic stroke risk and passive exposure to spouses' cigarette smoking. Melbourne Stroke Risk Factor Study (MERFS) Group. Am J Public Health. 1999;89(4):572-5.

26. Bonita R, Duncan J, Truelsen T, Jackson RT, Beaglehole R. Passive smoking as well as active smoking increases the risk of acute stroke. Tob Control. 1999:8(2):156-60.

27. Juster HR, Loomis BR, Hinman TM, Farrelly MC, Hyland A, Bauer UE, et al. Declines in hospital admissions for acute myocardial infarction in New York state after implementation of a comprehensive smoking ban. Am J Public Health. 2007;97(11):2035-9.

28. Helsing KJ, Sandler DP, Comstock GW, Chee E. Heart disease mortality in nonsmokers living with smokers. Am J Epidemiol. 1988;127(5):915-22.

29. Dunbar A, Gotsis W, Frishman W. Second-hand tobacco smoke and cardiovascular disease risk: an epidemiological review. Cardiol Rev. 2013:21(2):94-100

30. Institute of Medicine. Secondhand smoke exposure and cardiovascular effects: making sense of the evidence. Washington, D.C.: National Academic Press; 2010.

31. Kawachi I, Colditz GA, Speizer FE, Manson JE, Stampfer MJ, Willett WC, et al A prospective study of passive smoking and coronary heart disease. Circulation. 1997:95(10):2374-9.

32. Celermajer DS, Adams MR, Clarkson P, Robinson J, McCredie R, Donald A, et al. Passive smoking and impaired endothelium-dependent arterial dilatation in healthy young adults. N Engl J Med. 1996;334(3):150-4.

33. Glantz SA, Parmley WW. Passive smoking and heart disease. Mechanisms and risk. JAMA. 1995;273(13):1047-53.
34. Kritz $H$, Schmid $P$, Sinzinger $H$. Passive smoking and cardiovascular risk. Arch Intern Med. 1995:155(18):1942-8.

35. Law MR, Wald NJ. Environmental tobacco smoke and ischemic heart disease. Prog Cardiovasc Dis. 2003:46(1):31-8.

36. Antó JM, Vermeire P, Vestbo J, Sunyer J. Epidemiology of chronic obstructive pulmonary disease. Eur Respir J. 2001;17(5):982-94.

37. Nikula KJ, Green FH. Animal models of chronic bronchitis and their relevance to studies of particle-induced disease. Inhal Toxicol. 2000;12 Suppl 4:123-53.

38. California Environmental Protection Agency. Health Effects of Exposure to Environmental Tobacco Smoke. In. Office of Environmental Health Hazard Assessment: Sacramento; 1997.

39. Eisner MD, Balmes J, Yelin EH, Katz PP, Hammond SK, Benowitz N, et al. Directly measured secondhand smoke exposure and COPD health outcomes. BMC Pulm Med. 2006;6:12.

40. Menezes AM, Hallal PC. Role of passive smoking on COPD risk in non-smokers. Lancet. 2007:370(9589):716-7.

41. Zhou Y, Wang C, Yao W, Chen P, Kang J, Huang S, et al. COPD in Chinese nonsmokers. Eur Respir J. 2009:33(3):509-18.

42. ASH. The health effects of exposure to secondhand smoke. In: Action on Smoking and Health. 2014

43. Iribarren C, Darbinian J, Klatsky AL, Friedman GD. Cohort study of exposure to environmental tobacco smoke and risk of first ischemic stroke and transient ischemic attack. Neuroepidemiology. 2004;23(1-2):38-44.

44. U.S. Department of Health and Human Services. The Health Consequences of Smoking-50 Years of Progress. A Report of the Surgeon General. In: Office on Smoking and Health. Atlanta, GA: U.S. Department of Health and Human Services, Centers for Disease Control and Prevention, National Center for Chronic Disease Prevention and Health Promotion; 2014.

45. Qureshi Al, Suri MF, Kirmani JF, Divani AA. Cigarette smoking among spouses: another risk factor for stroke in women. Stroke; a journal of cerebral circulation. 2005:36(9):e74-6

46. Donnan GA, McNeil JJ, Adena MA, Doyle AE, O'Malley HM, Neill GC. Smoking as a risk factor for cerebral ischaemia. Lancet. 1989:2(8664):643-7.

47. Howard G, Wagenknecht LE, Cai J, Cooper L, Kraut MA, Toole JF. Cigarette smoking and other risk factors for silent cerebral infarction in the general population. Stroke; a journal of cerebral circulation. 1998;29(5):913-7.

48. Glymour MM, Defries TB, Kawachi I, Avendano M. Spousal smoking and incidence of first stroke: the Health and Retirement Study. Am J Prev Med. 2008:35(3):245-8.

49. Oono IP, Mackay DF, Pell JP. Meta-analysis of the association between secondhand smoke exposure and stroke. J Public Health. 2011;33(4):496-502.

50. Pitsavos C, Panagiotakos DB, Chrysohoou C, Tzioumis K, Papaioannou I, Stefanadis $C$, et al. Association between passive cigarette smoking and the risk of developing acute coronary syndromes: the CARDIO2000 study. Heart Vessels. 2002;16(4):127-30.

51. Moher D, Liberati A, Tetzlaff J, Altman DG. Preferred reporting items for systematic reviews and meta-analyses: the PRISMA statement. PLoS Med. 2009;6(7):e1000097.

52. Stroup DF, Berlin JA, Morton SC, Olkin I, Williamson GD, Rennie D, et al Meta-analysis of observational studies in epidemiology: a proposal for reporting. Meta-analysis Of Observational Studies in Epidemiology (MOOSE) group. JAMA. 2000;283(15):2008-12.

53. La Torre G, Chiaradia G, Gianfagna F, De Laurentis A, Boccia S, Ricciardi W. Quality assessment in meta-analysis. Italian Journal of Public Health. 2006:3(2):44-50.

54. Spitzer WO, Lawrence V, Dales R, Hill G, Archer MC, Clark P, et al. Links between passive smoking and disease: a best-evidence synthesis. A report of the Working Group on Passive Smoking. Clin Invest Med. 1990;13(1):17-42. discussion 43-16.

55. From relative risks to odds ratios and back [http://www.epigear.com/index files/or2rr.html]. Accessed 22 Nov 2015.

56. Meta-analysis with MIX 2.0 [http://www.meta-analysis-made-easy.com/ index.html]. Accessed 22 Nov 2015.

57. DerSimonian R, Laird N. Meta-analysis in clinical trials. Control Clin Trials. 1986;7(3):177-88

58. Blettner M, Krahn U, Schlattmann P. Meta-analysis in epidemiology. In: Ahrens W, Pigeot I, editors. Handbook of epidemiology. New York: Springer; 2014. p. 1377-411.

59. Blettner M, Sauerbrei W, Schlehofer B, Scheuchenpflug T, Friedenreich C. Traditional reviews, meta-analyses and pooled analyses in epidemiology. Int J Epidemiol. 1999;28(1):1-9. 
60. Sutton AJ, Abrams KR, Jones DR, Sheldon TA, Song F. Methods for metaanalysis in medical research. John Wiley \& Sons, Ltd: Chichester; 2000.

61. Hedges LV, Olkin I. Statistical methods for meta-analysis. Orlando, FL: Academic; 1985

62. Higgins JP, Thompson SG. Quantifying heterogeneity in a meta-analysis. Stat Med. 2002;21(11):1539-58.

63. Kalandidi A, Trichopoulos D, Hatzakis A, Tzannes S, Saracci R. The effect of involuntary smoking on the occurrence of chronic obstructive pulmonary disease. Soz Praventivmed. 1990;35(1):12-6.

64. Johannessen A, Bakke PS, Hardie JA, Eagan TM. Association of exposure to environmental tobacco smoke in childhood with chronic obstructive pulmonary disease and respiratory symptoms in adults. Respirology (Carlton, Vic. 2012;17(3):499-505.

65. Steenland K, Thun M, Lally C, Heath Jr C. Environmental tobacco smoke and coronary heart disease in the American Cancer Society CPS-II cohort. Circulation. 1996;94(4):622-8.

66. He Y, Lam TH, Li LS, Li LS, Du RY, Jia GL, et al. Passive smoking at work as a risk factor for coronary heart disease in Chinese women who have never smoked. BMJ. 1994;308(6925):380-4

67. Panagiotakos DB, Chrysohoou C, Pitsavos C, Papaioannou I, Skoumas J, Stefanadis $C$, et al. The association between secondhand smoke and the risk of developing acute coronary syndromes, among non-smokers, under the presence of several cardiovascular risk factors: The CARDIO2000 case-control study. BMC Public Health. 2002;2:9.

68. Rosenlund M, Berglind N, Gustavsson A, Reuterwall C, Hallqvist J, Nyberg F, et al. Environmental tobacco smoke and myocardial infarction among never-smokers in the Stockholm Heart Epidemiology Program (SHEEP). Epidemiology (Cambridge, Mass). 2001;12(5):558-64.

69. Ciruzzi M, Pramparo P, Esteban O, Rozlosnik J, Tartaglione J, Abecasis B, et al. Case-control study of passive smoking at home and risk of acute myocardial infarction. Argentine FRICAS Investigators. Factores de Riesgo Coronario en America del Sur. J Am Coll Cardiol. 1998;31(4):797-803.

70. McElduff P, Dobson AJ, Jackson R, Beaglehole R, Heller RF, Lay-Yee R. Coronary events and exposure to environmental tobacco smoke: a case-control study from Australia and New Zealand. Tob Control. 1998;7(1):41-6.

71. Yin P, Jiang CQ, Cheng KK, Lam TH, Lam KH, Miller MR, et al. Passive smoking exposure and risk of COPD among adults in China: the Guangzhou Biobank Cohort Study. Lancet. 2007;370(9589):751-7.

72. Chan-Yeung $M$, Ho AS, Cheung AH, Liu RW, Yee WK, Sin KM, et al. Determinants of chronic obstructive pulmonary disease in Chinese patients in Hong Kong. Int J Tuberc Lung Dis. 2007;11(5):502-7.

73. Wen W, Shu XO, Gao YT, Yang G, Li Q, Li H, et al. Environmental tobacco smoke and mortality in Chinese women who have never smoked: prospective cohort study. BMJ. 2006;333(7564):376.

74. Zhang X, Shu XO, Yang G, Li HL, Xiang YB, Gao YT, et al. Association of passive smoking by husbands with prevalence of stroke among Chinese women nonsmokers. Am J Epidemiol. 2005;161(3):213-8.

75. Wu CF, Feng NH, Chong IW, Wu KY, Lee CH, Hwang JJ, et al. Second-hand smoke and chronic bronchitis in Taiwanese women: a health-care based study. BMC Public Health. 2010;10:44.

76. Lee PN, Forey BA. Environmental tobacco smoke exposure and risk of stroke in nonsmokers: a review with meta-analysis. J Stroke Cerebrovasc Dis. 2006;15(5):190-201.

77. Sauerbrei W, Blettner M, Royston P. On alcohol consumption and all-case mortality. J Clin Epidemiol. 2001;54(5):537-40.

78. Singh RJ, Lal PG. Second-hand smoke: A neglected public health challenge. Indian J Public Health. 2011;55(3):192-8.

79. Baron JA, La Vecchia C, Levi F. The antiestrogenic effect of cigarette smoking in women. Am J Obstet Gynecol. 1990;162(2):502-14.

80. Geisler J, Omsjo IH, Helle SI, Ekse D, Silsand T, Lonning PE. Plasma oestrogen fractions in postmenopausal women receiving hormone replacement therapy: influence of route of administration and cigarette smoking. J Endocrinol. 1999;162(2):265-70.

81. Hsieh CC, Signorello LB, Lipworth L, Lagiou P, Mantzoros CS, Trichopoulos D. Predictors of sex hormone levels among the elderly: a study in Greece. J Clin Epidemiol. 1998;51(10):837-41.

82. Bolego C, Poli A, Paoletti R. Smoking and gender. Cardiovasc Res. 2002;53(3):568-76.

83. Bero LA, Glantz SA, Rennie D. Publication bias and public health policy on environmental tobacco smoke. JAMA. 1994;272(2):133-6.
84. Shamliyan T, Kane RL, Dickinson S. A systematic review of tools used to assess the quality of observational studies that examine incidence or prevalence and risk factors for diseases. J Clin Epidemiol. 2010;63(10):1061-70.

85. Dreier M, Borutta B, Stahmeyer J, Krauth C, Walter U. Comparison of tools for assessing the methodological quality of primary and secondary studies in health technology assessment reports in Germany. GMS Health Technol Assess. 2010;6:Doc07.

86. Hardy RJ, Thompson SG. Detecting and describing heterogeneity in metaanalysis. Stat Med. 1998;17(8):841-56.

87. Dobson AJ, Alexander HM, Heller RF, Lloyd DM. Passive smoking and the risk of heart attack or coronary death. Med J Aust. 1991;154(12):793-7.

88. Gallo V, Neasham D, Airoldi L, Ferrari P, Jenab M, Boffetta P, et al. Second-hand smoke, cotinine levels, and risk of circulatory mortality in a large cohort study of never-smokers. Epidemiology (Cambridge, Mass). 2010;21(2):207-14.

89. He Y, Jiang B, Li LS, Li LS, Ko L, Wu L, et al. Secondhand smoke exposure predicted COPD and other tobacco-related mortality in a 17-year cohort study in China. Chest. 2012;142(4):909-18.

90. Hill SE, Blakely T, Kawachi I, Woodward A. Mortality among lifelong nonsmokers exposed to secondhand smoke at home: cohort data and sensitivity analyses. Am J Epidemiol. 2007;165(5):530-40.

91. Hole DJ, Gillis CR, Chopra C, Hawthorne VM. Passive smoking and cardiorespiratory health in a general population in the west of Scotland. BMJ. 1989;299(6696):423-7.

92. Jefferis BJ, Lawlor DA, Ebrahim S, Wannamethee SG, Feyerabend C, Doig M, et al. Cotinine-assessed second-hand smoke exposure and risk of cardiovascular disease in older adults. Heart. 2010;96(11):854-9.

93. Muscat JE, Wynder EL. Exposure to environmental tobacco smoke and the risk of heart attack. Int J Epidemiol. 1995;24(4):715-9.

94. Rostron B. Mortality risks associated with environmental tobacco smoke exposure in the United States. Nicotine Tob Res. 2013;15(10):1722-8.

95. Schwartz AG, Cote ML, Wenzlaff AS, Van Dyke A, Chen W, Ruckdeschel JC, et al. Chronic obstructive lung diseases and risk of non-small cell lung cancer in women. J Thorac Oncol. 2009;4(3):291-9.

96. Whincup PH, Gilg JA, Emberson JR, Jarvis MJ, Feyerabend C, Bryant A, et al. Passive smoking and risk of coronary heart disease and stroke: prospective study with cotinine measurement. BMJ. 2004;329(7459):200-5.

\section{Submit your next manuscript to BioMed Central and take full advantage of:}

- Convenient online submission

- Thorough peer review

- No space constraints or color figure charges

- Immediate publication on acceptance

- Inclusion in PubMed, CAS, Scopus and Google Scholar

- Research which is freely available for redistribution 